\title{
The Effectiveness of Internal Controls in Rural Community Banks: Evidence from Ghana
}

\author{
Du Jianguo \\ Professor, Jiangsu University, School of Management, P.R China \\ E-mail: jgdu2005@163.com
}

Rauf Ibrahim (Corresponding author)

Jiangsu University, School of Management, P.R China

E-mail: rauljovial@yahoo.com

Peter Lartey Yao

School of Finance and Economics, Jiangsu University, P.R China

E-mail: efopeter@yahoo.com

Rupa Jaladi Santosh

Welingkar Institute of Management Development \& Research, India

E-mail: rupa.jaladi@gmail.com

Amponsah Clinton Kwabena

Jiangsu University, P.R China

E-mail: klintoamponsah@gmil.com

Received: April 1, 2019 Accepted: May 28, 2019 Published: June 30, 2019

doi:10.5296/bms.v10i1.15003ＵRL: https://doi.org/10.5296/bms.v10i1.15003 


\section{Abstract}

Internal control is relevant in every business establishment, though its presence may not be a guarantee that fraud and corporate scandals would cease to occur. From the rural banking communities in Ghana, this study examines the significance of internal control element on the performance of elected rural banks. The statistical analysis and inferential judgment is based on the responses gathered from 650 bank employees on the functioning of internal controls. Based on the quantitative results and analysis, the study found a highly significant relationship between internal controls and performance of banks with respect to the principles prescribed by the Committee of Sponsoring Organization of the Treadway Commission framework -COSO. There exist a very strong internal control systems in the rural banks of Ghana, however monitoring, control activities and issues of corporate governance need to be addressed.

Keywords: Internal Control, Risk Assessment, Control Environment, Good governance 


\section{Introduction}

The banking and financial industry has gone through a series catastrophes in past couple of years, with a significant numbers of them folding up due to cases of fraud, losses resulting from market risk, internal control and cooperate governance weaknesses (Barra 2010). The collapse of banks resulting from financial distress is of major concerns to the Central Bank and government due to the economic contribution to the country's GDP (Dowdell, Kim et al. 2013). Between 2016 and 2018, Ghana witnessed the collapse of seven local banks and many others left under the life support programs by the Central Bank (Asiedu and Deffor 2017). The sad demise of these banks were attributed to gross disregard for internal control, managerial greed and bad corporate governance. Banks are said to have some of the most efficient and effective internal controls systems, however, the industry still suffers a great deal of fraud, financial and accounting scandals resulting in heavy losses (Callahan and Soileau 2017). Major concerns to banks with regards to internal control responsibilities include safeguarding the bank's assets, preventing unauthorized access to volts, approvals and access to accounting entries systems and passwords. Other major concerns include the fear of money laundering and compliance with transfers regulations as well as capital requirements to meet adequate liquidity requirement (Bellavite Pellegrini, Meoli et al. 2017). Bank failures such Lehman Brothers was due to fraud, and it has been a subject of reference in the study of internal control, likewise major corporate failures across Europe and America such as Enron and WorldCom, which subsequently compelled the US government to implement several regulations to protect the interest of investors and the public with the introduction of Sarbanes Oxley Act2002 and Subsequently the Committee of Sponsoring Organizations of the Treadway Commission (Martin, Sanders et al. 2014). These regulations brought relief to investor and stakeholders with reasonable assurance that their investments are protected from losses. That is the heritage of internal controls, as it serve as the cornerstone for achieving the organizational objectives through a series of procedures designed by management and board and places the responsibility on the shoulders of the people working in the organization, meaning that internal control is the responsibility of everyone working within the organization (Tekathen and Dechow 2013). According to the pioneers of internal control failure to observe the principles could leave an organization in a state of chaos and state of ineffectiveness and lack of cooperation between major components of the organization. In order to achieve high operational efficiency, integrity of the people, accuracy and reliability of accounting and financial reporting the principles of internal controls must be observed (Agyei-Mensah 2016). The failure to apply effective internal controls to mitigate risk and address increasing tendencies of fraud has left many organizations to experience large corporate scandals. Although internal control does not automatically guarantee the absence of fraud and irregularities, it contributes to effective management of people and resources. Since the effectiveness of controls are subject to changes over a period of time , every internal control systems requires consistent evaluation (Ahluwalia, Ferrell et al. 2016), measuring internal control is a continues process, since controls can be good today but fails the following years due to increasing and new 


\section{Macrothink

dimensions of corporate and organizational risk. This study is determined to examine the effectiveness of internal controls in rural community banks in Ghana to assess their effectiveness, in the wake of reforms after the collapse of major banks in Ghana. It is also a means of evaluating how the rural banks are responding the Central Banks directives and policies on internal controls and corporate governance in this critical period where the banking a d financial industry is going through a series of reforms. The research questions we sought to answer is are the rural banks using employing the right internal controls principles.

\section{Theatrical Foundation and Literature Review}

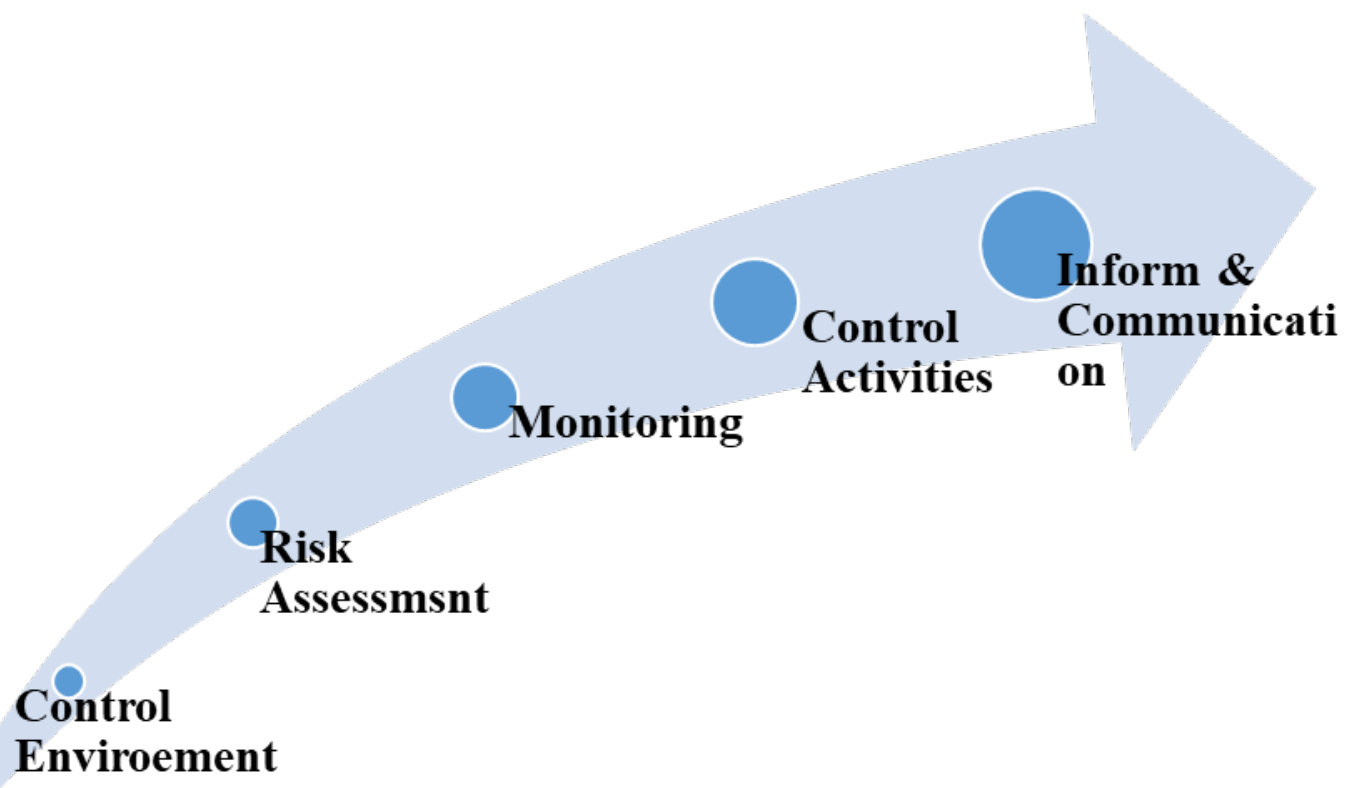

Sources: (COSO, 2013)

\subsubsection{Internal Control Effectiveness and Performance}

The definition of internal control is given by COSO, (2013), as a set of continuous process and procedures. This is so because the processes are not an end by itself but rather a means to an end. It constitute the strategic polices deveopled by an organization through a collective effort and contributions by the people, from the board to the lower level, to ensure that they provide a reasonable assurance that objectives of the organization are met and that all the resources under the control of these organization including the people are protected and controlled in manner that will help realize the strategic goals (Li, Raman et al. 2015). The main objectives are, the controls should be able to help the organization achieve maximum operational efficiency, compliance with regulations, accounting process and practical follow ethical standards and reporting follows reliable format (Lawson, Muriel et al. 2017). Other definitions are the Basel Committee on Banking Supervision, also termed internal control as a responsibility of the board of directors to direct operations of the organization in an orderly, 
legal and ensure activities take into account ethical considerations. The impact of internal control on the performance of an organizations depends on a wide range of factors, including the understanding, implementation, supervising and applying suitable controls to required risks. In most where controls fails, there outcome has always been, management failure to apply the right controls. Additionally, internal control elements are inter-dependent on each other, therefore if the firms fails to ensure efficiency of each control component the entire system of control can be compromised while attempting to facilitate business processes (Nurhayati 2016). Ideally effective controls systems are embedded in the business and organizational processes and form an integral part of the corporation. In order for controls to be effective and impact positively on performance, it has to be designed and made the responsibility of everyone, from the board, management and employees. Everyone within the organization is responsible for ensuring that internal controls function effectively.

\subsubsection{Control Environment}

Control environments are the actual standards, processes and structures that provides the foundation for other internal controls throughout the organization (Archer 2016). This may include the tone at the tone at the top, also means the attitude of top management. Example, the CEO's attitude towards internal control goes a long way to set a positive tone for the entire organization. Does the CEO sees internal control as something that will actually drive the success of the organization, is it is something that is vital or they are just being forced to comply with controls, but actually not committed to it (Basu 2016). If the CEO is an ethical person and takes internal control very seriously, that will affect the success of internal control right from the top the bottom of the structure. Likewise the top management, the control environment can be looked at from employee's commitment point view point, thus the attitude of employees towards controls. Studies have suggested that, the positive or posture of the CEO, will affect the attitude of the lower employees (Boadu 2016). If the CEO or even the board does not demonstrate commitment to internal control there is no way the lower employees will comply with it This implies that, control environment is very important in setting the attitude of the entire organization as a cultural value as a support mechanism to other components of controls. Adhikari and Gårseth-Nesbakk (2016), most scholar refers to control environment as the message management send across the organization about internal controls, such as issues bothering on integrity, ethical values , the operating philosophy , leadership tendencies of management overriding controls . The philosophy of management towards result-oriented policies is evident in the control environment, if only they possess high quality of competence as well encourage employees to also upgrade and become competent along with their increasing responsibilities (Gurd and Helliar 2017) There are several players within the control environment and that includes the audit committee of the board, who are required to demonstrate high level of competence, integrity and independence in ensuring effective internal control. The board itself and the sub-committees may be subject to integrity scrutiny such as looking at the ratio of executive and non-executive members discharging the strategic duties. 


\subsubsection{Risk Assessment}

Every organization is exposed to risk and it is the responsibility of management, internal and external auditors to help identify risk (Dong, Girardone et al. 2017). The organizational risk assessment process involves identification and managing any type of risk that the business faces. How this relates to auditors, financial statement, companies should be assessing the risk of financial statement fraud and that is going be built around the company's internal control systems. Managing and identifying risk should be able to tell that this is the risk the organizational is willing able to address with full consideration of the resource capacity (Aziz, Rahman et al. 2015). Management must be able to identify risk, as it is one of the major principles underlined in the Sarbanes Oxley Act 2002. Identifying factors that may increase risk and estimating the significance of the risk is very critical to control effectiveness. Aside that, assessing the likelihood of risk occurring and determining the required action is necessary to managing the risk. According (Dănescu, Prozan et al. 2015), managing risks, assessing policies and programs varies, but is closely related to the auditors judgment. Management assesses risk related to designing and operating internal control in order to minimize errors and fraud. Auditors assess risk to decide the evidence needed in the audit. These are guidelines, prescribe by COSO and Sarbanes Oxley Act2002 which mandates firms to issues reports on internal controls and make public their financial statements timely (Renault, Agumba et al. 2016). The increasing involvement of external evaluators in the assessment of risk and internal control effectiveness, has encouraged firm not to demonstrate much commitment assessing their internal affairs with respect to risk.

\subsubsection{Control Activities}

These are policies, procedures that are put in place to address risk that have been identified. They come along with policies like separation of duties, authorization, physical control access to company documents and installations, passwords etc, Are good examples of control activities Reconciliations of the cash account to the bank balance (Arslanalp and Liao 2014). All these measures could be installed to address any form of irregularity in financial operations including fraud as well as errors and potential threats to accuracy of accounting records (Barton and Bruder 2014). Control activities are the actions taken based on auditors recommendation and internal auditors assessment of the state of controls. Most often these actions in the form of directives from the board to effect changes to operational policies and systems. Hayes, Wallage et al. (2014), controls activities include a set policies such as adequate separation of duties, meaning two separate or related functions cannot be performed by one individual, and under certain circumstances processes that are jointly performed should not be assigned to close employees eg billing of customers, cashiering bank lodgment, deposits and withdrawals (Lawson, Muriel et al. 2017). These actions also ensures that proper authorization of transactions and financial records are put in place , for examples , granting credit facilities to customers and loans must be approved and monitored by designated superior (Apostolou, Dull et al. 2013). Aside that, adequate documentation and recording of data are relevant aspects of control activities. Similar to this is access to vital 
information. Safeguarding assets is paramount responsibility of control activity, and it could be physical control over assets and records (Daniela and Attila 2013). In a computerized accounting environment, passwords are required before entry to gain access to master files. At the same time, independent checks must be carried out and independently verified. In most cases, especially with the banks employees in custody of assets are separated from those in charge of authorization of transaction (Lawson, Muriel et al. 2017). Employees in charge of assets storage are separated from those in charge of book-keeping. At the same time, IT personnel are separated far away from all user departments.

\subsubsection{Information and Communication}

This is an important critical element, tool for effective internal control, example if a company has an accounting system that is not providing quality financial information or seem to be unreliable, there would certainly be doubt about the recording of the data and transitions (Soin and Collier 2013). The biggest risk is that, there may be losses, in assets and revenue leakages without proper traces and that would certainly make it difficult to measure performance of the organization at any given time (Martin, Sanders et al. 2014). It also an indication that the internal control responsibilities may not have been adequately communicated to those at the lower level who are actually doing the work, and therefore the quality of internal control does not reflect the responses in productivity. More so communication and information is vital in creating the linkage between all the other elements of controls. It provides feedback on the effectiveness of each control component. Dănescu and Dogar (2012), found a positive impact of internal control on employee performance with the help of effective channels of communication, the establishment of effective mode of communication in an organization, and frequent assessment for consistent feedback from bottom up and vice versa. The purpose of accounting information is and communication is to initiate, record, process and report the entity's transactions and to maintain accounting for related assets.

\subsection{Monitoring}

Monitoring has the responsibility of evaluating performance of internal control to identify deviations and inefficiencies associated with the system of controls (Benaroch, Chernobai et al. 2012). Ideally, internal control shouldn't be left unmonitored or assessed for effectiveness, Monitoring also verifies and ensures whether people are actually applying the internal control designed and if the designed controls are addressing specific risk that it's meant to address (Dowdell, Kim et al. 2013). However, the controls help management to identify any problems with the operating environment. Negative responses could imply that the controls systems weak and ineffective. Monitoring controls require that, people in top management make abreast themselves, especially the board with the concept of control system that is suitable for the organization and assess how the said controls addresses the interest of all parties (Tessier and Otley 2012). Board of directors are mandated to acquire requisite knowledge to be able to understand the level of risk the firm is exposed to and then create a risk program to address them. The board is also mandated to take part in monitoring, without their 
involvement it will be challenging for management alone to address the effectiveness of internal controls in any strange circumstances (Chtioui and Thiéry-Dubuisson 2011). Computerization of accounting systems have made it much easier for firms to monitor employees and accounting systems, however it is much of problem if the board is not abreast with new technologies that will support their oversight responsibilities (Ma and Ma 2011). Likewise, the other elements of controls, monitoring also requires consistency and continuous process and ongoing procedures.

\section{Methodology}

The study involves a sample of 650 bank employees from 12 local community banks from six regions of Ghana with most rural banks. The regions are the Eastern region, Volta region, Central region, Upper west, Upper East region and Ahafo region. These regions have the most rural engaging in farming activities. The study then resorted to primary data through questionnaire, administered to employees holding various positions in these commercial banks. Management and boards members were therefore excluded from the target respondents, to avoid bias. The researcher believes that the responses from employees will give a clear view and understanding of the effectiveness of internal controls as well inform our judgment on whether internal controls are built with the consideration of employees are well programmed to involve everyone since controls are the responsibilities of everyone within the organization. The questionnaire was drafted using the components of internal controls are the constructs as it was previously used by Kong et.al (2018). The independent variables are; Control Environment, Risk Assessment, Monitoring, Control Activities and Information and Communication. These are estimated to influence effective management and organizational performance.

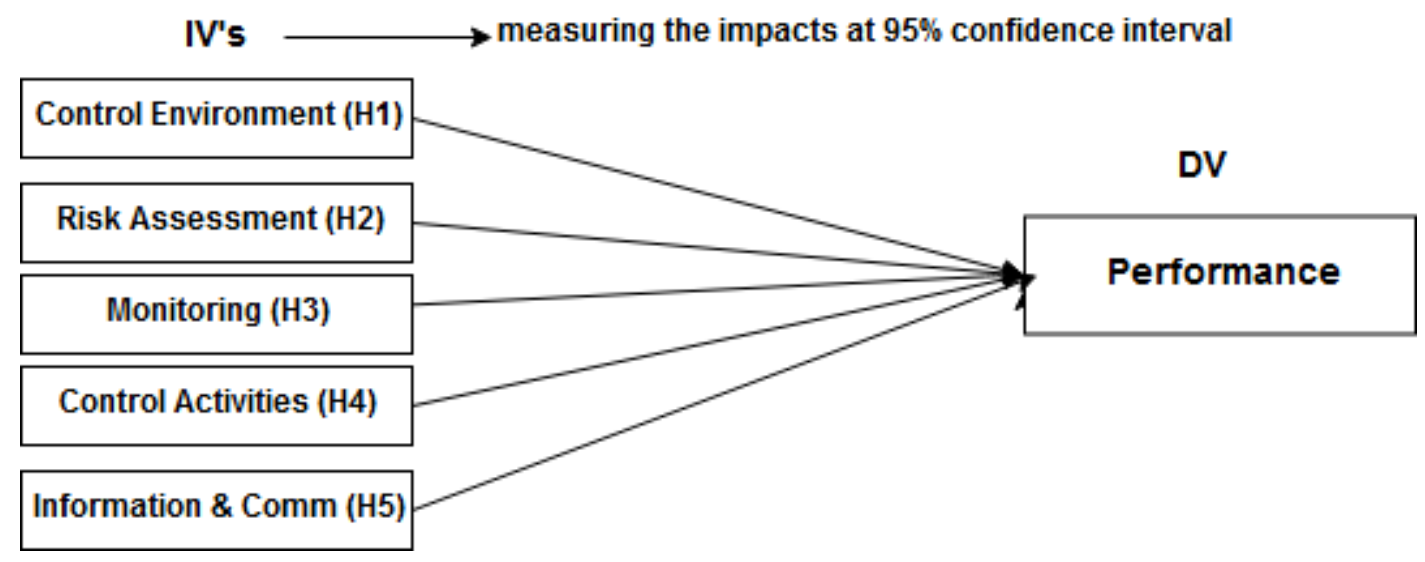

Figure 1. The Research Framework

Authors' design

The questionnaire was also measured on a five point Likert scale, indicating that 5 , represents a strongly agree to the statement, while 4 represents agree, 3 no idea, 2 disagree and 1 , denoting strongly disagree. Section A, involves respondents person information (Age, gender, department years of experience in the field (Colbert, Nussenblatt et al. 2018). The 
departments include; Finance, Cashiering, Internal Auditing, Administration, transport and HR department. The main theoretical framework supporting this study is the principles in internal controls found in the framework of the Committee of Sponsoring Organizations of the Treadway Commission, also called the COSO Framework, published in 1992 (Lawson, Muriel et al. 2017). Evidence justifying the use of the model and the elements as independent variables can be found in major previous studies such as (Gupta 2008). We used Stata and SPSS software to perform a regression analysis to estimate the degree of association correlation and coefficients. Crombach's alpha is used to determine the level of reliability of all the constructs prior to the analysis, (see table 1). The figures suggest that, the constructs fit the criteria of validity and could be used for further analysis.

Table 1. Reliability Test - Crombach’s Alpha

\begin{tabular}{|l|l|}
\hline Constructs & Crombach's Alpha \\
\hline Control Environment & 0.780 \\
\hline Risk Assessment & 0.087 \\
\hline Monitoring & 0.902 \\
\hline Control Activities & 0.801 \\
\hline Information and Communication & 0.867 \\
\hline Performance & 0.890 \\
\hline
\end{tabular}

Authors Computation

\subsubsection{Empirical Results}

From the researchers' viewpoint, the selected models will make a clear predictions between internal control and performance (Hill and Jones 1992). Given that the study is non-economic in nature, we intend to depend on basic econometric tools such as the three staged-least-square regression technique and correlation to give a clear interpretation to the evidence gathered from respondents (Knechel 2007). The research by implication is merely an effort to objectively evaluate the application of internal control in rural banks and based on the analysis we could infer whether or not there exist a causal effect between " $\mathrm{X}$ " and " $\mathrm{Y}$ " variables in order to inform policy makers on practical decisions that will overturn the negative implications of weak internal control in rural banks in Ghana.

The choice of variables represent a major research gap we identified after surveying a wide range of literature discussing the state of internal controls challenges in most developing 
countries after decades of reforms. In (table 2), a brief summary of the statistical information on the data set such the variables in the data set, the 650 observations, the mean which basically measures the central tendency of the explanatory variable.Then the standard deviation which also measures the variability in the data set as well as the minimum and maximum thresholds of measurement

Table 2. Descriptive Statistics

\begin{tabular}{|c|c|c|c|c|c|}
\hline sum & & & & & \\
\hline Variable & Obs & Mean & Std. Dev. & Min & $\operatorname{Max}$ \\
\hline education & 650 & 2.062366 & .8600213 & 1 & 4 \\
\hline experience & 650 & 2.305376 & .9566426 & 1 & 4 \\
\hline department & 650 & 1.423656 & .4946694 & 1 & 2 \\
\hline environment & 650 & 9.053763 & 1.586348 & 7 & 16 \\
\hline risk assessment & 650 & 9.974194 & 1.367488 & 8 & 16 \\
\hline monitoring & 650 & 9.888172 & 2.538575 & 7 & 17 \\
\hline control activities & 650 & 9.015054 & 2.095199 & 8 & 16 \\
\hline inform \& comm & 650 & 8.686022 & 2.213867 & 7 & 16 \\
\hline performance & 650 & 9.384946 & 1.725877 & 8 & 16 \\
\hline
\end{tabular}

Table 3, present a correlation matrix stating the relationship between the dependent and independent variables. The result suggest that all the constructs measured positive correlation coefficients without correlating with itself. However, the independent variables statistically correlate with the dependent variable which seem to suggest that the relationship is very significant.

We could infer from this point that, the hypothetical assumption underlining this study which states that there is no relationship between the independent variables and performance, may be rejected as there is evidence of strong statistical significance. The parameters in this results qualifies the study for further robust analysis, with exception of a negative correlation between monitoring and performance. This implies that all the controls elements are effectively applied except monitoring, and as a result banks unable to identify and efficiently 
manage risks and major threats to their control systems. The implication of this result would be discussed further in the conclusion.

Table 3. Correlation Result

\begin{tabular}{|ccccccc|}
\hline CONSTRUCTS & PEF & ENV & RISK & MON & CAT & IFC \\
\hline PEF & 1 & & & & & \\
ENV & $.602^{* *}$ & 1 & & & & \\
RISK & $.702^{* *}$ & $.615^{* *}$ & 1 & & \\
MON & $-.246^{* *}$ & $-.202^{* *}$ & $-.233^{* *}$ & 1 & & \\
CAT & $.503^{* *}$ & $.739 * *$ & $.802^{* *}$ & $.800^{* *}$ & 1 & \\
IFC & $.164^{* *}$ & $.692^{*}$ & $.503^{*}$ & .222 & .145 & 1 \\
& & & & & & \\
\end{tabular}

\section{Authors computations}

\section{Three staged-Least Square regression}

As we seek to comfirm the results in the previouse table (table 3 ) above, we sought to make estimate the impacts of internal control effectiveness on performance. The model however, shows a strong predictiting ability of the constructs.

The R-sqaure value is 0.9390 (see table 4). By implication the null hypothesis could be rejected given the confidence level of $95 \%$ correspong to positive coeficients and $\mathrm{Z}$ tests. Unlike the correllation result that produced a nagetive value for monitoring, the regression rather shows a weak inflrunce by control activities The implication is that, based on the ineffective monitoring, the control activities initiatedd to check the financial irregualarities and performance deficiencies might be wrongly applied. It should be noted that, the components of internal control are inter-dependent and if one element is weeak it could compromise the effectiveness of the other. This is evience from the results, as the control activities looked insignificant at 0.865. All the other independent variables are said to have relatively significant inpact on perormance and having a high coeffiecient. Meaning that any unit increases in the values of these variable could result in a significant improvement on internal controls. 
Table 4. Regression Result

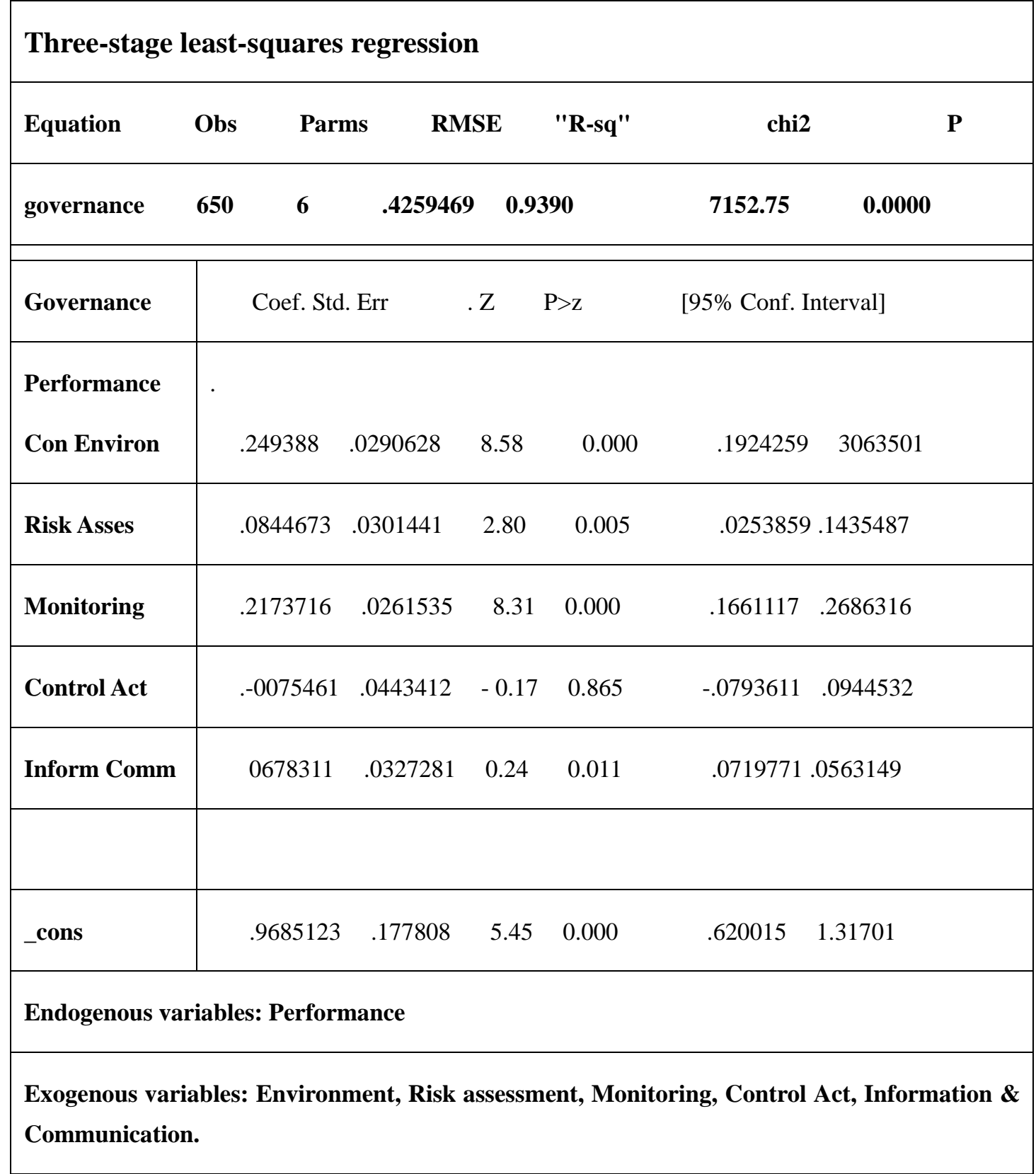

With their positive coefficient and a significant $\mathrm{p}$-values, the three staged least square possesses a strong expalantory power for all variables for further inferential judgements.

The result seem to suggest that stakeholders, manageement and policy makers have a strong basis to effect changes in their approach to internal controls by upholding the selected principles used in this analysis in order to protect the firm investment agianst losses and fraud.

\section{Discussion}

The consequences of weak internal controls far outweigh its merits. Every now and then, it is either a company is laying off workers or permanent closure. It appears the famous Enron's 
case keeps repeating itself, as the operations of many businesses are being threatened by bad control systems, governance and scheming leadership (Ji, Lu et al. 2017). The principal responsibility of board is to ensure efficient allocation of resources belonging to the corporation in a manner that will increase stakeholder's value (Afiah and Azwari 2015). Recent happening in the financial sector of Ghana has cast doubt on the relevance of corporate governance in the sustainability strong internal controls in the banking sector. This study however proposes that there is a strong relationship between internal controls and performance of rural banks, but issues of monitoring and control activities need to be improved.

Despite the role of the central bank as the principal regulator of the economy and the financial sector, it failed to save the seven banks from collapsing within one year with thousands of people rendered unemployed (Appiah, Asamoah et al. 2016). The concept is often overlooked in the large banks, and per the results, the weaknesses of internal controls is mostly common among large banks operating on large scale. Meanwhile the devastating impact is consequently endured by the ordinary depositors. After a careful consideration of the results in this study, we identified strong determinants of internal effectiveness to control environment, risk assessment, information and communication and monitoring, but the most prominent factor is control environment with a high coefficient influence in both correlation and regression.

\section{Conclusion}

The outcome of this study remains a positive contribution to one of most critical issues confronting the banking and financial sector of Ghana.

The researchers based their inferential judgment on a sound statistical application and current trends in accordance with relevant theories on the subject matter. The study identified a statistically significant relationships between determinants of effective controls and performance (table 3 and 4), in anticipation of a positive rate of change. However, based on the wide spread of non-compliance to ethical standards across the banking sector, we sought to advocate for the formation of a competent board with majority independent non-executive directors

However, this study is of a different opinion that board chairpersons be denied appointment, that would only grant them the avenue to closely relate and get involved with management and possibly breed corruption, greed, victimization, high level conflict of interest or even undermine their successors which could result in power struggle and internal wrangling (Aguilera and Cuervo-Cazurra 2004). There are also a few studies recommending that former CEO's or directors could actively contribute to improve governance in the capacity of nonexecutive members to the board or act as consultants for the sake of knowledge management especially where the organization is unable to find instant replacement or better still act as resource persons for capacity building and training programs for employees (Bahrawe, Haron et al. 2016). 
According to Francoeur, Labelle et al. (2008), the audit committee's work is more relevant to the governance system of an organisation and can be more beneficial if adequate steps are taken to elect align independent member who are not affiliated to management to head the committee. Although the work of an audit committee is highly influential in corporate governance, it does not receive much recognition in the rural banks.

\section{Acknowledgement}

This research is supported by the School of Management, Jiangsu University

\section{References}

Adhikari, P., \& Gårseth-Nesbakk, L. (2016). Implementing public sector accruals in OECD member states: Major issues and challenges. Accounting Forum, 40(2), 125-142.

Afiah, N. N., \& Azwari, P. C. (2015). The Effect of the Implementation of Government Internal Control System (GICS) on the Quality of Financial Reporting of the Local Government and its Impact on the Principles of Good Governance: A Research in District, City, and Provincial Government in South Sumatera. Procedia - Social and Behavioral Sciences, 211, 811-818.

Aguilera, R. V., \& A. Cuervo-Cazurra (2004). Codes of good governance worldwide: what is the trigger? Organization studies, 25(3), 415-443.

Agyei-Mensah, B. K. (2016). Impact of Adopting IFRS in Ghana: Empirical Evidence. Economics and Political Implications of International Financial Reporting Standards, IGI Global: 191-230.

Ahluwalia, S., et al. (2016). Sarbanes-Oxley Section 406 Code of Ethics for Senior Financial Officers and Firm Behavior. Journal of Business Ethics, 1-13.

Apostolou, B., et al. (2013). A framework for the pedagogy of accounting ethics. Accounting Education, 22(1), 1-17.

Appiah, K. O., et al. (2016). Nomination committee-board gender diversity nexus in Ghana. International Journal of Business Governance and Ethics, 11(2), 135-158.

Archer, J. G. (2016). This SOX: Combating Public Charity Fraud with Sarbanes-Oxley.

Arslanalp, S., \& Y. Liao (2014). Banking sector contingent liabilities and sovereign risk. Journal of Empirical Finance, 29, 316-330.

Asiedu, K. F., \& Deffor, E. W. (2017). Fighting Corruption by Means of Effective Internal Audit Function: Evidence from the Ghanaian Public Sector. International Journal of Auditing.

Aziz, M. A. A., et al. (2015). Enhancement of the Accountability of Public Sectors through Integrity System, Internal Control System and Leadership Practices: A Review Study. Procedia Economics and Finance, 28, 163-169. 
Bahrawe, S. H., et al. (2016). Corporate Governance and Auditor Independence in Saudi Arabia: Literature Review and Proposed Conceptual Framework. International Business Research, 9(11), 1.

Barra, R. A. (2010). The impact of internal controls and penalties on fraud. Journal of information systems, 24(1), 1-21.

Barton, H., \& Bruder, N. (2014). A guide to local environmental auditing, Routledge.

Basu, S. K. (2016). Auditing \& Assurance, Pearson Education India.

Bellavite Pellegrini, C., et al. (2017). Money market funds, shadow banking and systemic risk in United Kingdom. Finance Research Letters, 21, 163-171.

Benaroch, M., et al. (2012). An internal control perspective on the market value consequences of IT operational risk events. International Journal of Accounting Information Systems, 13(4), 357-381.

Boadu, M. (2016). Ethical Dimensions of Corporate Governance Practice in Ghana: Developing a Theoretical Perspective. Corporate Governance in Africa, Springer, 97-130.

Callahan, C., \& Soileau, J. (2017). Does Enterprise risk management enhance operating performance? Advances in Accounting, 37, 122-139.

Chtioui, T., \& Thiéry-Dubuisson, S. (2011). Hard and soft controls: mind the gap! International Journal of Business, 16(3), 289.

COSO (2013). COSO Internal Control —-Integrated Framework Principles. C o m m i t te e of Sponsoring Organizations of the Treadway Commi s s i o n - www.coso.org

Colbert, M. C., et al. (2018). Chapter 3 - Integrity in Research: Principles for the Conduct of Research. Principles and Practice of Clinical Research (Fourth Edition). J. I. Gallin, F. P. Ognibene and L. L. Johnson. Boston, Academic Press: 33-46.

Dănescu, T., \& Dogar, C. (2012). COSO Principles and European Social Fund Funded Projects in Romania. Procedia - Social and Behavioral Sciences, 62, 901-905.

Dănescu, T., et al. (2015). Aspects Regarding Risks in Financial Reporting. Procedia Economics and Finance, 23, 161-167.

Daniela, P., \& T. Attila (2013). Internal Audit versus Internal Control and Coaching. Procedia Economics and Finance, 6, 694-702.

Dong, Y., et al. (2017). Governance, efficiency and risk taking in Chinese banking. The British Accounting Review, 49(2), 211-229.

Dowdell, T. D., et al. (2013). Internal control reporting and market liquidity. Research in Accounting Regulation, 25(1), 30-40. 
Francoeur, C., et al. (2008). Gender diversity in corporate governance and top management. Journal of Business Ethics, 81(1), 83-95.

Gupta, P. P. (2008). Management's evaluation of internal controls under Section 404 (a) using the COSO 1992 control framework: Evidence from practice. International Journal of Disclosure and Governance, 5(1), 48-68.

Gurd, B., \& Helliar, C. (2017). Looking for leaders: 'Balancing' innovation, risk and management control systems. The British Accounting Review, 49(1), 91-102.

Hayes, R., et al. (2014). Principles of auditing: an introduction to international standards on auditing, Pearson Higher Ed.

Hill, C. W., \& Jones, T. M. (1992). Stakeholder-agency theory. Journal of management studies, 29(2), 131-154.

Ji, X.-d., et al. (2017). Voluntary Disclosure of Internal Control Weakness and Earnings Quality: Evidence From China. The International Journal of Accounting, 52(1), 27-44.

Kong, Y. L., Peter, B. F., \& Biswas, N. (2018). Administrative Sciences 2076-3387.8(3) 40. The Value of Public Sector Risk Management: An Empirical Assessment of Ghana. https://doi.org/10.3390/admsci8030040

Knechel, W. R. (2007). The business risk audit: Origins, obstacles and opportunities. Accounting, Organizations and Society, 32(4), 383-408.

Lawson, B. P., et al. (2017). A survey on firms' implementation of COSO's 2013 Internal Control-Integrated Framework. Research in Accounting Regulation 29(1), 30-43.

Li, C., et al. (2015). The SOX 404 internal control audit: Key regulatory events. Research in Accounting Regulation, 27(2), 160-164.

Ma, J., \& C. Ma (2011). Factor Analysis Based On The COSO Framework And The Goverment Audit Performance Of Control Theory. Procedia Engineering, 15, 5584-5589.

Martin, K., et al. (2014). The potential impact of COSO internal control integrated framework revision on internal audit structured SOX work programs. Research in Accounting Regulation, 26(1), 110-117.

Nurhayati (2016). Revealing and Building the COSO Concept and Khalifatullah Fill Ard Philosophy to Prevent and Detect the Occurrence of Fraud Through Forensic Accounting. Procedia - Social and Behavioral Sciences, 219, 541-547.

Renault, B. Y., et al. (2016). Drivers for and Obstacles to Enterprise Risk Management in Construction Firms: A Literature Review. Procedia Engineering, 164, 402-408.

Soin, K., \& P. Collier (2013). Risk and risk management in management accounting and control. Management Accounting Research, 24(2), 82-87. 


\section{Macrothink}

Business Management and Strategy ISSN 2157-6068

Tekathen, M., \& Dechow, N. (2013). Enterprise risk management and continuous re-alignment in the pursuit of accountability: A German case. Management Accounting Research, 24(2), 100-121.

Tessier, S., \& Otley, D. (2012). A conceptual development of Simons' Levers of Control framework. Management Accounting Research, 23(3), 171-185.

\section{Copyright}

Copyright for this article is retained by the author(s), with first publication rights granted to the journal.

This is an open-access article distributed under the terms and conditions of the Creative Commons Attribution license (http://creativecommons.org/licenses/by/4.0/). 